\title{
Soil tillage practices and crops rotations effects on yields and chemical properties of a lixisol in Burkina Faso
}

\author{
Bazoumana Koulibaly 1(*), Déhou Dakuo ${ }^{2}$, Karim Traoré ${ }^{1}$, Adama Ouattara ${ }^{1}$, Korodjouma Ouattara ${ }^{1}$, \\ Ouola Traoré 3 \\ 1 Institute of Environment and Agricultural Research (INERA), Cotton Program; 01 BP 208 Bobo-Dioulasso 01, Burkina \\ Faso. Tél: (226) 20972105 \\ ${ }^{2}$ Burkinabe Society of Textile Fibres (SOFITEX), Direction of cotton production development, Bobo-Dioulasso, Burkina \\ Faso. \\ ${ }^{3}$ West African Economic and Monetary Union (UEMOA), Ouagadougou, Burkina Faso. \\ (*) Author for correspondences E-mail: bazoumana@hotmail.com
}

Original submitted in on $5^{\text {th }}$ September 2016. Published online at www.m.elewa.org on $31^{\text {st }}$ October 2016 http://dx.doi.org/10.4314/jab.v106i1.12

\begin{abstract}
Objective: To improve soil chemical properties and crops productivity, this study was conducted from 2008 to 2015, on lixisoil in a research station, using reduced soil tillage and leguminous plant cover.

Methodology and Results: Three soil tillage practices in main plot (T1 = no tillage with direct sowing, T2 = minimum tillage by soil scarifying with IR12 tool and T3 = conventional tillage with animals drawn plough) were compared and combined to four crops rotation systems, in a split-plot experimental design. Soil chemical characteristics and crops yields were evaluated. The results showed that tillage practices did not influence significantly the soil chemical properties, but soil organic matter contents, nitrogen, phosphorus and potassium were lower in conventional tillage plots (T3) compared to minimum tillage (T2) and no tillage (direct sowing). Rotations did not significantly influence nitrogen and soil organic matter contents, even the leguminous mucuna insertion in the rotation during three years. After 8 years, crops rotations improved significantly cotton (Gossypium hirsutum L.) and maize (Zea mays L.) yields. The yield increases were respectively $+7,+23$ and $+43 \%$, with one, two and three years of mucuna insertion into rotations. No tillage (direct sowing) and minimum tillage (scarifying with IR12) were as efficacy as conventional tillage on Mucuna and maize yields whereas cotton yield, with minimum tillage (T2) was significantly higher than no tillage (T1).

Conclusion and application of results: The study showed that conventional tillage with mouldboard plough, appear to be the soil tillage practice, which led to soil properties degradation. Crops rotations with the use of leguminous mucuna allowed reducing soil $\mathrm{N}$ contents decreases. No tillage (direct sowing) and minimum tillage (scarifying with IR12) showed same efficacy with conventional tillage on cotton, maize and mucuna yields, which were improved after mucuna insertion into crops rotations. Therefore, tillage suppression or its reduction combined to one year leguminous cover plant insertion in rotation (mucuna-cotton-maize) could be used for crops diversification and sustainable productivity in cotton and cereals based production systems.
\end{abstract}

Keywords: Tillage practices, crops rotations, plant cover, soil fertility, yields, Burkina Faso. 


\section{RESUME}

Effets des techniques de travail du sol et des rotations sur les rendements des cultures et les propriétés chimiques d'un sol ferrugineux tropical au Burkina Faso

Objectif: L'étude vise à évaluer les effets de la réduction du travail du sol et de l'introduction d'une légumineuse en plante de couverture dans les rotations sur les propriétés chimiques du sol et la productivité des cultures. Méthodologie et résultats: Le dispositif expérimental est un split-plot comportant trois modes de travail du sol en traitement principal (T1: zéro labour, T2: scarifiage à la dent IR12 en traction bovine et T3: labour à la charrue en traction bovine) combinés à quatre rotations à base de coton (Gossypium hirsutum L.), de maïs (Zea mays L.) et du mucuna, utilisé comme plante de couverture. Les caractéristiques chimiques du sol et les rendements des cultures ont été évalués. Les résultats montrent que les teneurs en matière organique, en azote, en phosphore et en potassium du sol, statistiquement homogènes, ont baissé avec le labour (T3) par rapport au scarifiage à la dent IR 12 (T2) et au zéro labour (T1). L'introduction d'une légumineuse dans les rotations n'a pas influencé les teneurs en azote et en matière organique du sol, mais elle $a$, par contre, significativement augmenté les rendements du cotonnier et entrainé, sur le maïs, des suppléments de production respectifs de $+7,+23$ et $+43 \%$, avec une, deux et trois années de mucuna dans les rotations.

Conclusion et application des résultats: L'étude a permis de montrer que le labour est le mode de préparation du sol le plus défavorable pour les caractéristiques chimiques du sol, peu influencées par les rotations des cultures, qui réduisent la baisse des teneurs en $\mathrm{N}$ avec l'utilisation de la légumineuse mucuna. Le zéro labour (semis direct) et le scarifiage à la dent IR12 se sont révélés aussi efficaces que le labour sur les rendements des cultures, eux même, améliorés par l'introduction du mucuna dans les rotations. De ce fait, une suppression du labour ou sa réduction, combinée à une année d'insertion de la légumineuse mucuna, en plante de couverture, dans la rotation (mucuna-coton-maïs), pourrait être envisagée pour le maintien des propriétés du sol et une amélioration durable des rendements dans les systèmes de production à base de coton et de céréales.

Mots clés: travail du sol, rotations culturales, plante de couverture, fertilité du sol, rendements, Burkina Faso.

\section{INTRODUCTION}

Soil fertility degradation is considered to be_one of the major limiting factors of agricultural productivity in Sub-Saharan African countries (Bationo et al., 2012; Busari et al., 2015). Among the reasons of this progressive land degradation, cultivation systems, soil tillage practices, are particularly often cited by various studies (Ouattara et al., 2006; Maia et al., 2010; Schneider et al., 2010). In Burkina Faso, crop production systems and soil fertility management are particularly based on the use of mineral fertilizers associated to soil tillage; mainly ploughing at the beginning of the rainy season (Ouédraogo et al., 2014; Traoré, 2016). However, cotton (Gossypium hirsutum L.) is grows on soils which generally havea low fertility level, fragile and sensitive to erosion (Zougmoré et al., 2006; Sawadogo et al., 2008; Barro et al., 2009). These soils are generally subjected to the runoff and erosion phenomena, depending on excessive tillage, involving a loss of soil nutrients and organic matter (Pallo et al., 2009;
Barro et al., 2009; Pouya et al., 2013). Thus, mechanized tillage using tractor and animal traction, increases soil physical and chemical degradation than manual cultivation and fallow, leading to soil acidification (Koulibaly et al., 2014). Conventional farming practices are no longer sustainable as far as soil fertility is concerned. Moreover, strong anthropic pressure on soil leads to a drastic decrease of crops yields (Yaméogo et al., 2013; Traoré, 2016). In addition, for a few decades throughout the world, ploughing has been decreasing at the profit of various tillage practices, ranging from reduced tillage without reversal, to direct seeding (Reddy et al., 2003, Veiga et al., 2008; Lefèvre, 2013). In Burkina Faso cotton farming areas, various studies recommended a reduction of ploughing frequency for better preservation of soil properties (every two years) and a minimum tillage, in crop production (Ouattara et al., 2006). Rainfall irregularity involves unfavourable conditions with ploughing, which lead 
to sowing delays, and therefore reduce cotton yields (Traoré, 2016). In Burkina Faso, as for the majority of West African countries, several fertility management practices including using of organic matter, mineral fertilizers or introduction of leguminous plants into rotations were adopted for their efficacy (Bado, 2002; Mando et al., 2005; Bationo et al., 2012; Karuma et al., 2014). It is therefore necessary, for a sustainable soil fertility management, to analyze tillage practices effects and

\section{MATERIALS AND METHODS}

Experimental site and material description: This study was conducted in 2008 on the research station of Farako-bâ ( 4020 W Longitude, $11^{0} 06$ N Latitude, 405 m). Climate is south-Sudanese type, with a rainy season ranging between May and October, and a dry season, from November to April. During 2008 to 2015, the annual rainfall was between 831 and $1289 \mathrm{~mm}$, received during 62 to 79 days. Plants cropped were cotton and maize (Zea mays L.) completed with a cover plant. Cotton to determine the impact of crops rotations including leguminous plant as cover crop. The objective of this study is to determine the tillage practices effects associated to crops rotations integrating a plant cover, on soil chemical properties and crops yields. Research hypothesis is that soil properties and crops yields can be improve by soil tillage reduction and by introduction of a leguminous plant as cover crop in rotations.

variety FK 37 , with 150 days cycle and 3.5 tha- 1 of seed cotton as potential yield was used. Maize variety FBC 6 , with 110 days cycle length, and 3.5 tha- 1 as potential yield, was also cultivated. Mucuna cochinchinensis variety, which cycle is from 130 to 150 days (Figure 1), was integrated as cover crop in cotton and maize rotations. Soil tillage practices consisted to use the plough for conventional tillage and "IR12 tool" for a minimum tillage by scarifying soil with animal traction.

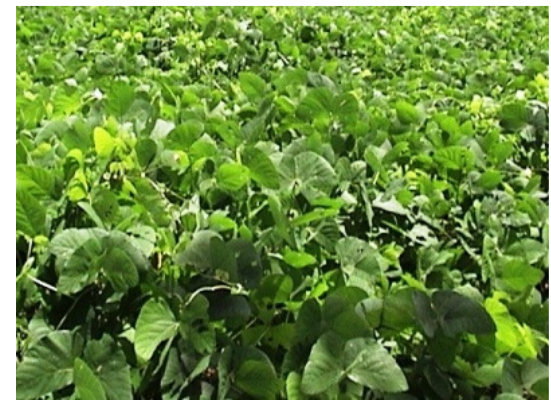

A) Soil recovered by Mucuna

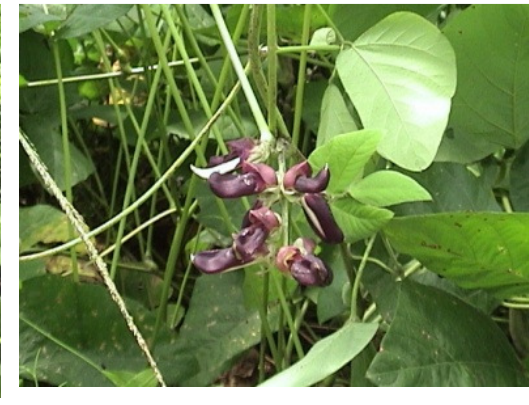

B) Flowering of Mucuna

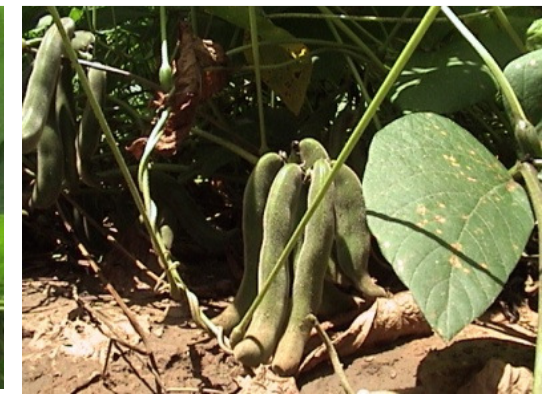

C) Fruiting of Mucuna

Figure 1: Pictures of leguminous plant cover Mucuna cochinchinensis.

Mineral fertilizers: Mineral fertilization of cotton and maize was ensured by NPKSB (14-18-18-6S-1B) and urea [CO $\left(\mathrm{NH}_{2}\right)_{2}$ ] with $46 \%$ nitrogen content.

Experimental design: The study was conducted on a lixisol, in a split-plot experimental design with three tillage practices combined to four crops rotations with four replications. Main treatments consist of three tillage practices: $\mathrm{T} 1=$ no-till (direct sowing), $\mathrm{T} 2$ = scarifying by IR12 tool and T3 = conventional tillage with animals drawn plough. Secondary treatments were four crop rotations (Table 1):

$\mathrm{R} 1=$ Cotton-maize (control without cover plant) - (c-m), $\mathrm{R} 2$ = Mucuna-cotton-maize (one year of Mucuna in three years rotation) - (1muc-c-m),
R3 = Mucuna-mucuna-cotton-maize (two years of Mucuna in four years rotation) - (2muc-c-m),

R4 = Mucuna-mucuna-mucuna-cotton (three years of Mucuna in four years rotation) - (3muc-c).

Experimental unit $\left(60 \mathrm{~m}^{2}\right)$ was a plot consisted of five 15 $\mathrm{m}$ length rows, spaced $0.80 \mathrm{~m}$ apart. A surface of $240 \mathrm{~m}^{2}$ was assigned to each main plot and $2280 \mathrm{~m}^{2}$ for the experiment. In the first year of study (2008), soil was ploughed by a tractor at an average depth of $25 \mathrm{~cm}$, and then harrowed. From the second year (2009), according to above mentioned main treatments, conventional tillage was carried out by animal traction ( $15 \mathrm{~cm}$ of depth), and minimum tillage by IR12 tool scarifying, from 7 to $10 \mathrm{~cm}$ depth, depending on soil moisture status. Cotton, maize and mucuna were sown in seed holes, drawn aside by 


\section{Koulibaly et al. J. Appl. Biosci. 2016 Soil tillage practices and crops rotations effects on yields and chemical properties of a lixisol in Burkina Faso}

$0.40 \mathrm{~m}$, then thinned out 15 days after emergence, with two plants per seed hole, to obtain a theoretical density of 62500 plants per hectare. Crop sowings were carried out between June 27 and July 24, depending on years (Table 1).

Table 1. Crops rotations, sowing dates and rainfall from 2008 to 2015

\begin{tabular}{lllllllll}
\hline \multirow{2}{*}{ Rotations } & \multicolumn{7}{c}{ Years } \\
\cline { 2 - 9 } & $\mathbf{2 0 0 8}$ & $\mathbf{2 0 0 9}$ & $\mathbf{2 0 1 0}$ & $\mathbf{2 0 1 1}$ & $\mathbf{2 0 1 2}$ & $\mathbf{2 0 1 3}$ & $\mathbf{2 0 1 4}$ & $\mathbf{2 0 1 5}$ \\
\hline R1. c-m & Cotton & Maize & Cotton & Maize & Cotton & Maize & Cotton & Maize \\
R2. 1 muc-c-m & Mucuna & Cotton & Maize & Mucuna & Cotton & Maize & Mucuna & Cotton \\
R3. 2 muc-c-m & Mucuna & Mucuna & Cotton & Maize & Mucuna & Mucuna & Cotton & Maize \\
R4.3 muc-c & Mucuna & Mucuna & Mucuna & Cotton & Mucuna & Mucuna & Mucuna & Cotton \\
\hline Soil tillage dates & $17 / 06$ & $10 / 07$ & $30 / 06$ & $10 / 07$ & $6 / 07$ & $18 / 07$ & $25 / 06$ & $6 / 07$ \\
\hline Sowing dates & $27 / 06$ & $24 / 07$ & $7 / 07$ & $16 / 07$ & $10 / 07$ & $23 / 07$ & $2 / 07$ & $9 / 07$ \\
\hline Rainfall $(\mathrm{mm})$ & 1139,6 & 908,0 & 1289,5 & 831,0 & 1089,0 & 1126,0 & 1142,9 & 1050,9 \\
\hline
\end{tabular}

Cotton and maize mineral fertilization was carried by 150 $\mathrm{kg} \mathrm{ha}^{-1}$ of cotton fertilizer (14-18-18-6S-1B). It was applied 15 days after the emergence, and by $50 \mathrm{~kg} \mathrm{ha}^{-1}$ of urea, at 40 days. Mucuna cochinchinensis plant, used as cover crop was not fertilized. Weeds control on these two crops, was carried out by herbicides applications $\left(800 \mathrm{~g} \mathrm{ha}^{-1}\right.$ of diuron for cotton and $1250 \mathrm{~g} \mathrm{ha}^{-1}$ of pendimethalin for maize) supplemented by mechanical weeding. Cotton protection was ensured by usual insecticides applying indoxacarb (150 $\left.\mathrm{g} \mathrm{ha}^{-1}\right)$, at 30 and 44 days after emergence, "zeta-cypermethrin (12 $\left.\mathrm{g} \mathrm{ha}^{-1}\right)$ - profenofos (200 $\left.\mathrm{g} \mathrm{ha}^{-1}\right)$ " association at 58 th and 72 th days, and "cypermethrin (36 g ha-1) - acetamiprid (8 $\left.\mathrm{g} \mathrm{ha}^{-1}\right)$ " association with the $86^{\text {th }}$ and 100 th days. After harvests, the stems of cotton and maize were exported out of field while the mucuna biomass was preserved on the soil.

\section{RESULTS}

Tillage practices and rotations effects on soil organic matter and nitrogen content: Tillage practices and crops rotations did not have significant effects on soil organic matter and nitrogen contents, which decreased from 2011 to 2015 , as well as on $0-10 \mathrm{~cm}$ surface layer than deeper $10-20 \mathrm{~cm}$ layer (Table 2). On 0-10 cm layer of soil, from 2011 to 2015, organic matter contents decrease was $20 \%$, in rotations (cotton-maize) R1 and (mucuna-cotton-corn) R2. A moderate decrease of soil organic matter from 4 to $12 \%$ was noted in rotations R3 (2 $\mathrm{m}-\mathrm{c}-\mathrm{m}$ ) and R4 (3muc-c), where Mucuna was used during
Measurements: Soil was sampled in sub plots to determine the evolution of it chemicals characteristics. Thus, 96 soil samples were taken on $0-10$ and $10-20 \mathrm{~cm}$ layers depth in 2011 and 2015. All the soil samples were crushed and filtered at $2 \mathrm{~mm}$, for analyzes at the laboratory of the Bureau National des sols of Burkina Faso. The crop yields were evaluated by the harvest of three central lines of each sub plot.

Data analysis: Collected data were subjected to an analysis of variance (ANOVA), by GENSTAT 9.2. Student-Newman-Keuls test was used for means comparison when the analysis of variance reveals significant differences between treatments at $5 \%$ probability level.

two and three years in four years crop rotation. Soil tillage practices did not influence nitrogen contents, which, by 2011 to 2015, decrease was more important in rotations $\mathrm{R} 1$ and R2, compared to R4 rotation (Table 2). Introduction of leguminous plant Mucuna in rotations $R 2$ (1muc-c-m), R3 (2 m-c-m) and R4 (3muc-c) during respectively, one, two and three years, did not improve soil nitrogen content, as well as on surface $0-10 \mathrm{~cm}$ and 10-20 cm depth layer, compared to control rotation R1 (cotton-corn) without leguminous plant. 
Table 2. Soil organic matter and nitrogen contents (layer 0-10 $\mathrm{cm}$ and $10-20 \mathrm{~cm}$ ) according to the tillage practices under crops rotations at 2011 and 2015.

\begin{tabular}{|c|c|c|c|c|c|c|c|c|}
\hline \multirow{3}{*}{ Treatments } & \multicolumn{4}{|c|}{ Soil organic matter (\%) } & \multicolumn{4}{|c|}{ Nitrogen (\%) } \\
\hline & \multicolumn{2}{|c|}{$0-10 \mathrm{~cm}$} & \multicolumn{2}{|c|}{$10-20 \mathrm{~cm}$} & \multicolumn{2}{|c|}{$0-10 \mathrm{~cm}$} & \multicolumn{2}{|c|}{$10-20 \mathrm{~cm}$} \\
\hline & 2011 & 2015 & 2011 & 2015 & 2011 & 2015 & 2011 & 2015 \\
\hline \multicolumn{9}{|l|}{ Soil tillage } \\
\hline T1. No tillage & 1,00 & 0,87 & 0,89 & 0,78 & 0,049 & 0,046 & 0,044 & 0,041 \\
\hline T2. Scarifying IR 12 & 1,01 & 0,83 & 0,90 & 0,68 & 0,048 & 0,044 & 0,045 & 0,036 \\
\hline T3. Conventional tillage & 0,99 & 0,86 & 0,93 & 0,75 & 0,048 & 0,045 & 0,044 & 0,039 \\
\hline \multicolumn{9}{|l|}{ Crops rotations } \\
\hline R1. c-m & $1,05^{a}$ & 0,84 & 0,88 & 0,70 & 0,051 & 0,044 & 0,043 & 0,038 \\
\hline R2. 1 muc-c-m & 1,02 & 0,82 & 0,92 & 0,75 & 0,049 & 0,044 & 0,045 & 0,039 \\
\hline R3. 2 muc-c-m & 1,01 & 0,89 & 0,93 & 0,78 & 0,048 & 0,046 & 0,045 & 0,041 \\
\hline R4.3 muc-c & 0,91 & 0,87 & 0,90 & 0,72 & 0,046 & 0,046 & 0,046 & 0,037 \\
\hline \multicolumn{9}{|l|}{ Probability (5\%) } \\
\hline Soil Tillage & 0,974 & 0,457 & 0,843 & 0,061 & 0,963 & 0,379 & 0,962 & 0,191 \\
\hline Rotations & 0,348 & 0,248 & 0,886 & 0,422 & 0,357 & 0,549 & 0,852 & 0,491 \\
\hline Soil Tillage $x$ Rotations & 0,880 & 0,022 & 0,690 & 0,976 & 0,921 & 0,925 & 0,708 & 0,046 \\
\hline
\end{tabular}

R1: Cotton-Maize; R2: Mucuna-Cotton-Maize; R3: Mucuna-Mucuna-Cotton-Maize; R4: Mucuna-Mucuna-Mucuna-Cotton.

Tillage practices and rotations effects on soil phosphorus content: According to analysis of variance (Table 3), the effects of soil tillage practices and crops rotations on $P$ total and $P$ available contents were statistically significant, particularly on the surface $0-10 \mathrm{~cm}$ depth layer. On this layer, in 2011 and 2015, scarifying with IR12 tool (T2) was statistically equivalent to conventional tillage (T3) and decreased significantly total $P$ content compared to no tillage (T1). However, conventional tillage (T3) induced more important available $P$ declining in $0-10 \mathrm{~cm}$ depth layer in 2011. Soil tillage practices, in particular scarifying with IR12 tool, is seem to increase total $P$ and available $P$ content, compared to zero tillage (T1). In rotations $R 3$ and $R 4$ with respectively two and three years of mucuna on four years crops rotation, the total $P$ contents on $0-10 \mathrm{~cm}$ decreased significantly compared to those of rotations $\mathrm{R} 1(\mathrm{~cm})$ and $\mathrm{R} 2$ (1m-c-m). Available P contents of R1 rotation (without leguminous plant) were significantly higher than those of rotations R2, R3 and R4, with respectively, one, two and three years of mucuna in four years crops rotations. Results showed that in rotations, total and available $\mathrm{P}$ contents decrease with the increase of mucuna cultivation years in rotations. These contents increased by 2011 to 2015 , as well on the surface on $0-10 \mathrm{~cm}$ as in-depth on
10-20 cm. In 2015, the interaction between soil tillage practices and crops rotations were significant for total $P$ contents whose high values were noted in absence soil tillage, with zero tillage.

Tillage practices and rotations effects on soil potassium: Results in Table 4 shows, in 2011 and 2015; that soil tillage, by scarifying with IR12 tool and conventional tillage, produced a reduction in soil total $\mathrm{K}$ and available $\mathrm{K}$ contents. In 2015 and on 0-10 cm layer, compared to zero tillage ( $\mathrm{T} 1)$, total $\mathrm{K}$ and available $\mathrm{K}$ contents significantly decreased with conventional tillage (T3), statistically equivalent to minimum tillage by scarifying with IR12 tool (T2). Soil tillage practices decreased potassium contents, which are accentuated by conventional tillage than scarifying with IR12 tool. Crops rotations did not have significant effects on soil total $\mathrm{K}$ and available $K$ contents (Table 4). These contents seem to decrease in rotations R3 and R4 where the lowest potassium contents were noted compared to rotations R1 and R2. Generally, although interactions between soil tillage practices and crops rotations are not significant, from 2011 to 2015, total $K$ decreased whereas an improvement of available $\mathrm{K}$ contents was noted on the layer $0-10 \mathrm{~cm}$. 


\section{Koulibaly et al. J. Appl. Biosci. 2016 Soil tillage practices and crops rotations effects on yields and chemical properties of a lixisol in Burkina Faso}

Table 3. Tillage practices effects on contents of total phosphorus and available phosphorus under crops rotations at 2011 and $2015(0-10$ and $10-20 \mathrm{~cm})$

\begin{tabular}{|c|c|c|c|c|c|c|c|c|}
\hline \multirow{3}{*}{ Treatments } & \multicolumn{4}{|c|}{$P$ total $\left(\mathrm{mg} \mathrm{kg}^{-1}\right)$} & \multicolumn{4}{|c|}{ P ass. (Bray1) (mg kg-1) } \\
\hline & \multicolumn{2}{|c|}{$0-10 \mathrm{~cm}$} & \multicolumn{2}{|c|}{$10-20 \mathrm{~cm}$} & \multicolumn{2}{|c|}{$0-10 \mathrm{~cm}$} & \multicolumn{2}{|c|}{$10-20 \mathrm{~cm}$} \\
\hline & 2011 & 2015 & 2011 & 2015 & 2011 & 2015 & 2011 & 2015 \\
\hline \multicolumn{9}{|l|}{ Soil tillage } \\
\hline T1. No tillage & $111 \mathrm{a}$ & $118^{a}$ & $110^{a}$ & $116^{a}$ & $2,09^{a}$ & $5,53^{a}$ & $1,21^{a}$ & $2,67^{a}$ \\
\hline T2. Scarifying IR 12 & $103^{b}$ & $108^{b}$ & 104 a & $114^{a}$ & $2,02^{a}$ & $4,57^{a}$ & $1,32^{a}$ & $2,31^{\mathrm{a}}$ \\
\hline T3. Conventional tillage & 107 ab & $111 \mathrm{ab}$ & $103^{a}$ & $105^{\mathrm{a}}$ & $1,62^{a}$ & $5,58^{\mathrm{a}}$ & $1,44^{a}$ & $2,63^{\mathrm{a}}$ \\
\hline \multicolumn{9}{|l|}{ Crops rotations } \\
\hline R1. c-m & $113^{a}$ & $112^{a}$ & $105^{\text {a }}$ & $112^{a}$ & $2,44^{a}$ & $7,89^{a}$ & $1,61^{a}$ & $2,92^{a}$ \\
\hline R2. 1 muc-c-m & $109 a$ & $112^{a}$ & $108^{a}$ & $113^{a}$ & $1,82^{b}$ & $5,73^{b}$ & $1,24 b$ & $2,62^{a}$ \\
\hline R3. 2 muc-c-m & $107 \mathrm{ab}$ & $115^{a}$ & $105^{a}$ & $109 a$ & $1,74^{b}$ & $3,66^{c}$ & $1,22^{b}$ & $2,46^{\mathrm{a}}$ \\
\hline R4.3 muc-c & $98^{b}$ & $111^{a}$ & $105^{a}$ & $112^{a}$ & $1,64^{b}$ & $3,64^{c}$ & $1,22^{b}$ & $2,14^{a}$ \\
\hline \multicolumn{9}{|l|}{ Probability (5\%) } \\
\hline Soil Tillage & 0,017 & 0,029 & 0,083 & 0,334 & 0,075 & 0,239 & 0,075 & 0,549 \\
\hline Rotations & 0,018 & 0,903 & 0,811 & 0,886 & 0,027 & $<0,0001$ & 0,027 & 0,262 \\
\hline Soil Tillage $x$ Rotations & 0,413 & 0,039 & 0,388 & 0,815 & 0,725 & 0,816 & 0,725 & 0,823 \\
\hline
\end{tabular}

R1: Cotton-Maize; R2: Mucuna-Cotton-Maize; R3: Mucuna-Mucuna-Cotton-Maize; R4: Mucuna-Mucuna-Mucuna-Cotton. Values followed with the same letter in each column did not differ statistically according to Student-Newman-Keuls test at $5 \%$ level of probability. s: significant; ns: not significant.

Table 4: Content of K total and K available according to tillage practices under crops rotations at 2011 and 2015 (layer 010 and $10-20 \mathrm{~cm})$.

\begin{tabular}{|c|c|c|c|c|c|c|c|c|}
\hline \multirow{3}{*}{ Treatments } & \multicolumn{4}{|c|}{$\mathrm{K}$ total $\left(\mathrm{mg} \mathrm{kg}^{-1}\right)$} & \multicolumn{4}{|c|}{$\mathrm{K}$ disponible $\left(\mathrm{mg} \mathrm{kg}^{-1}\right)$} \\
\hline & \multicolumn{2}{|c|}{$0-10 \mathrm{~cm}$} & \multicolumn{2}{|c|}{$10-20 \mathrm{~cm}$} & \multicolumn{2}{|c|}{$0-10 \mathrm{~cm}$} & \multicolumn{2}{|c|}{$10-20 \mathrm{~cm}$} \\
\hline & 2011 & 2015 & 2011 & 2015 & 2011 & 2015 & 2011 & 2015 \\
\hline \multicolumn{9}{|l|}{ Soil tillage } \\
\hline T1. No tillage & $1441^{a}$ & $1314^{a}$ & $1774^{a}$ & $1506^{a}$ & $86^{a}$ & $96^{a}$ & $75^{a}$ & $59 a$ \\
\hline T2. Scarifying IR 12 & $1380^{a}$ & $1171^{b}$ & 1563 a & $1396^{\mathrm{a}}$ & $79 a$ & $86^{a b}$ & $69 a$ & $57^{a}$ \\
\hline T3. Conventional tillage & $1318^{a}$ & $1155^{b}$ & 1468 a & $1385^{\mathrm{a}}$ & $71^{a}$ & $77^{\mathrm{b}}$ & $62^{a}$ & $51^{a}$ \\
\hline \multicolumn{9}{|l|}{ Crops rotations } \\
\hline R1. c-m & $1338^{a}$ & $1265^{a}$ & $1575^{a}$ & $1464^{\mathrm{a}}$ & $78^{a}$ & $91^{a}$ & $64^{a}$ & $57^{a}$ \\
\hline R2. 1 muc-c-m & $1494^{\text {a }}$ & $1217^{\mathrm{a}}$ & $1622^{a}$ & $1431^{\mathrm{a}}$ & $84^{a}$ & $93^{a}$ & $68^{a}$ & $57^{a}$ \\
\hline R3. 2 muc-c-m & $1377^{\mathrm{a}}$ & $1190^{a}$ & $1595^{\mathrm{a}}$ & $1421^{\mathrm{a}}$ & $81^{a}$ & $87^{a}$ & $70^{a}$ & $59^{a}$ \\
\hline R4.3 muc-c & $1311^{a}$ & $1180^{\mathrm{a}}$ & $1616^{a}$ & $1400^{\mathrm{a}}$ & $71^{\mathrm{a}}$ & $74^{\mathrm{a}}$ & $72^{a}$ & $50^{a}$ \\
\hline \multicolumn{9}{|l|}{ Probability (5\%) } \\
\hline Soil Tillage & 0,407 & 0,017 & 0,191 & 0,168 & 0,467 & 0,448 & 0,615 & 0,568 \\
\hline Rotations & 0,071 & 0,159 & 0,909 & 0,803 & 0,297 & 0,169 & 0,728 & 0,304 \\
\hline Soil Tillage $\times$ Rotations & 0,300 & 0,134 & 0,303 & 0,605 & 0,406 & 0,615 & 0,487 & 0,628 \\
\hline
\end{tabular}

R1: Cotton-Maize; R2: Mucuna-Cotton-Maize; R3: Mucuna-Mucuna-Cotton-Maize; R4: Mucuna-Mucuna-Mucuna-Cotton. Values followed with the same letter in each column did not differ statistically according to Student-Newman-Keuls test at $5 \%$ level of probability.

Tillage practices and rotations effects on soil pH: $\mathrm{pH}$ water values ranging between 4.58 and 5.40 , were not statistically influenced by soil tillage practices (Figure 2) and crops rotations (Figure 3). From 2011 to 2015, pH decreased as well on $0-10 \mathrm{~cm}$ layer as in-depth $10-20 \mathrm{~cm}$ layer. The highest decrease of $\mathrm{pH}$ water, which is $7 \%$ on
$0-10 \mathrm{~cm}$, was observed with the conventional tillage and a decrease of 3 and $4 \%$, respectively, in zero tillage and scarifying with IR12 tool. The reduction in the $\mathrm{pH}$ by soil tillage practices is more important in-depth $10-20 \mathrm{~cm}$ layer, than on surface $(0-10 \mathrm{~cm})$ layer. On this strongly acid soil, from 2011 to 2015, pH decrease into crops 
rotations, were between 4 to $5 \%$ on $0-10 \mathrm{~cm}$ layer, and 6 to $8 \%$, in-depth $10-20 \mathrm{~cm}$ layer. In rotations R3 and R4, respectively, with two and three years of leguminous plant mucuna, $\mathrm{pH}$ declining was important as well as in

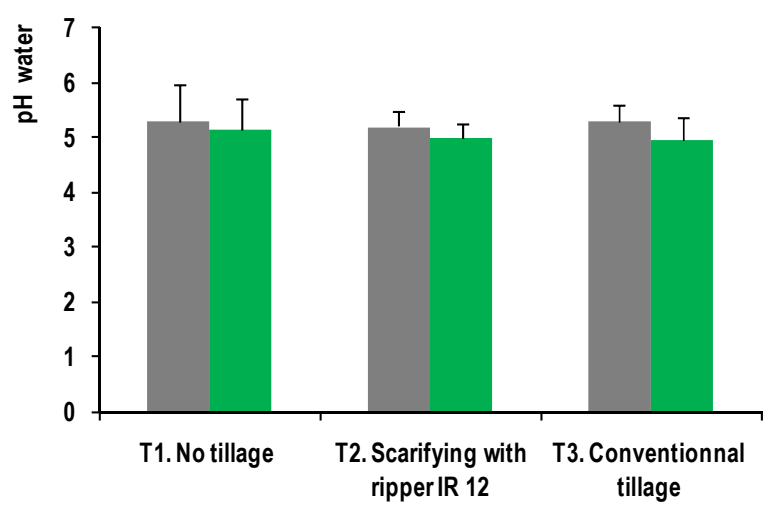

A) $\mathrm{pH}$ water on $0-10 \mathrm{~cm}$

$\because 2011=2015$ rotations R1 and R2. In general, compared to the conventional tillage and scarifying, $\mathrm{pH}$ declining was reduced by zero tillage.

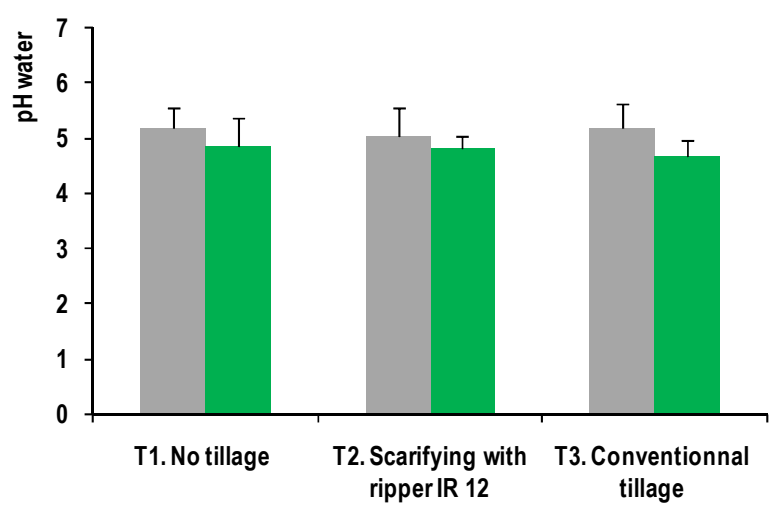

B) pH water on $10-20 \mathrm{~cm}$
$=2011 \square 2015$

Figure 2: Soil tillage practices effects on pH on 0-10 cm (A) and 10-20 cm (B) (2011 and 2015)

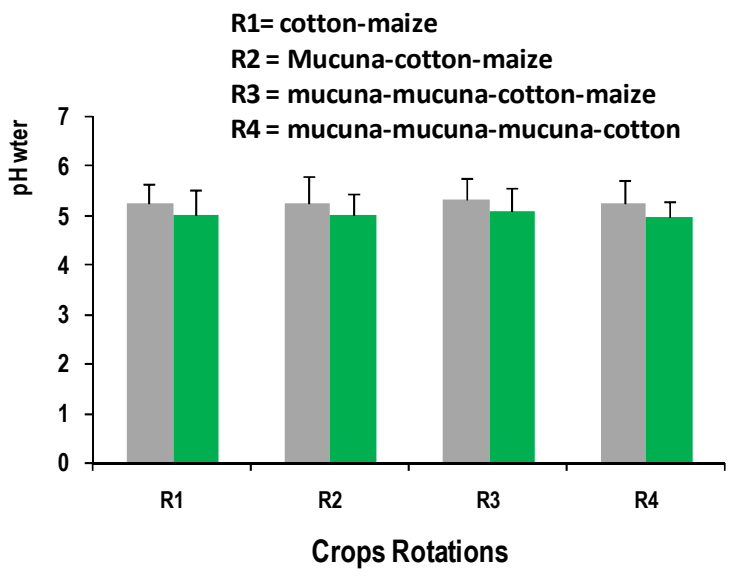

A) $\mathrm{pH}$ water on 0-10 cm $\square 2011 \square 2015$

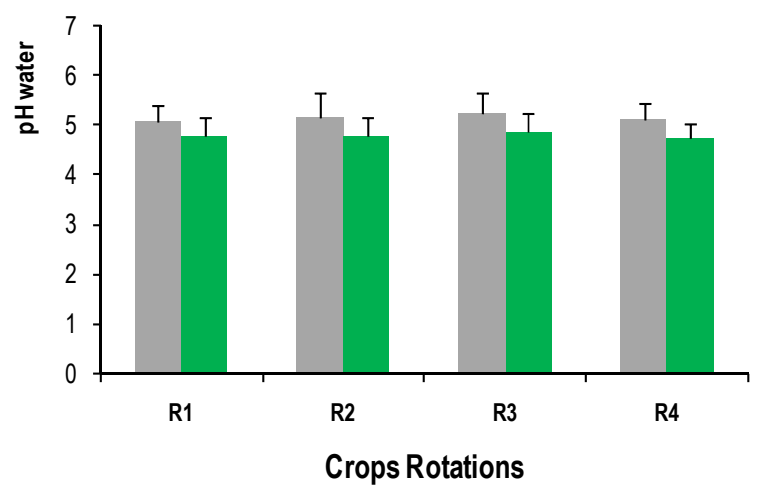

B) pH water on $10-20 \mathrm{~cm}$ $\square 2011 \square 2015$

Figure 3: Crops rotations effects on soil pH on 0-10 cm (A) and 10-20 cm (B) (2011 and 2015).

Tillage practices and rotations effects on crops yields: Variations of yields according to soil tillage practices into each crop rotation are presented in table 5 . In $\mathrm{R} 1$ rotation, conventional tillage had a positive effect on seed cotton yield in 2008 whereas it caused in 2013 on maize, a significant decrease of yield compared to scarifying with IR12 tool. In general, in four crops rotations, the yields were comparable with soil tillage (Table 5). After 8 years experimentation (2008 to 2015), soil tillage practices did not have significant effects on mucuna $(p=0.167)$ and maize $(p=0.753)$ yields (Table $6)$. Minimum tillage (scarifying with IR12 tool) improved seed cotton yield $(+4 \%)$ compared to conventional tillage which appeared to be better than no tillage (direct sowing). In opposite, no tillage (direct sowing) and minimum tillage gave better yields of maize which improvements were, respectively +17 and $+13 \%$, compared to conventional tillage. Crops rotations had significant effects on seed cotton and mucuna yields (Table 6). Compared to cotton-maize rotation (R1), 
introduction of a leguminous plant into rotations improved seed cotton yields with $+7,+23$ and $+43 \%$, respectively in rotations R3 (2muc-c-m), R2 (1muc-c-m) and R4 (3mucc). The rotations R2 (1muc-c-m) and R3 (2muc-c-m), with respectively, one and two years of mucuna cultivation, improved significantly the mucuna yield compared to rotation R4 (3muc-c). Rotations R4 (3muc-c), R3 (2muc$c-m)$ and R2 (1muc-c-m) allowed best yields of seed cotton, maize and mucuna, respectively. Compared to cotton-maize rotation without cover plant (R1), generally adopted by farmers, the rotation with one-year mucuna insertion (R2), gave yield surplus of seed cotton (+ $23 \%$ ) and maize $(+4 \%)$. Interactions between soil tillage practices and crops rotations were statistically significant on yields of cotton $(p=0.048)$ and maize $(p=0.003)$. The best options for cotton growing are conventional and minimum tillage (scarifying with IR12 which) which could be associate to no tillage (direct sowing) for maize production improvement. 
Table 5. Crops yields variations into rotations according to tillage practices

\begin{tabular}{|c|c|c|c|c|c|c|c|c|c|}
\hline \multirow{2}{*}{ Soil tillage } & \multirow{2}{*}{$\begin{array}{l}\text { Crops } \\
\text { rotations }\end{array}$} & 2008 & 2009 & 2010 & 2011 & 2012 & 2013 & 2014 & 2015 \\
\hline & & \multicolumn{8}{|c|}{$\mathrm{Kg} \mathrm{ha}^{-1}$} \\
\hline Crops & & Cotton & Maize & Cotton & Maize & Cotton & Maize & Cotton & Maize \\
\hline T1. No tillage & \multirow{3}{*}{$\begin{array}{l}\mathrm{R} 1 \\
\mathrm{c}-\mathrm{m}\end{array}$} & $882^{b}$ & $1153^{a}$ & $1080^{a}$ & $2428^{a}$ & $752^{a}$ & 2076 ab & $926^{a}$ & $2023^{a}$ \\
\hline T2. Scarifying IR 12 & & $1050^{a}$ & $1111^{a}$ & $1231^{\text {a }}$ & $2670^{a}$ & $857^{a}$ & $2395^{a}$ & 965 a & $2325^{a}$ \\
\hline T3. Conventional tillage & & 1076 a & $710^{a}$ & $1336^{a}$ & $1866^{a}$ & $817^{a}$ & $1527^{b}$ & $1293^{a}$ & $1578^{a}$ \\
\hline Probability (5\%) & & $\begin{array}{c}0,035 \\
(\mathrm{~s})\end{array}$ & $\begin{array}{l}0,126 \\
(\mathrm{~ns})\end{array}$ & $\begin{array}{c}0,244 \\
(\mathrm{~ns})\end{array}$ & $\begin{array}{l}0,16 \\
\text { (ns) }\end{array}$ & $\begin{array}{c}0,718 \\
(\mathrm{~ns})\end{array}$ & $\begin{array}{c}0,040 \\
(\mathrm{~s})\end{array}$ & $\begin{array}{c}0,688 \\
\text { (ns) }\end{array}$ & $\begin{array}{c}0,340 \\
\text { (ns) }\end{array}$ \\
\hline Crops & & Mucuna & Cotton & Maize & Mucuna & Cotton & Maize & Mucuna & Cotton \\
\hline T1. No tillage & \multirow{3}{*}{$\begin{array}{c}\mathrm{R} 2 \\
\text { 1muc-c-m }\end{array}$} & 849 a & $767^{a}$ & $1372^{a}$ & $433^{a}$ & $903^{a}$ & $2176^{a}$ & 1269 a & $597^{a}$ \\
\hline \multirow{2}{*}{$\begin{array}{l}\text { T2. Scarifying IR } 12 \\
\text { T3. Conventional tillage }\end{array}$} & & 852 a & $645^{b}$ & $1586^{a}$ & 582 a & $1087^{a}$ & 2334 a & 1389 a & $1037^{a}$ \\
\hline & & $832^{\text {a }}$ & 643 b & $1285^{a}$ & 369 a & $876^{\text {a }}$ & $1693^{a}$ & 1389 a & $906^{a}$ \\
\hline Probability (5\%) & & $\begin{array}{l}0,985 \\
(\mathrm{~ns})\end{array}$ & $\begin{array}{c}0,041 \\
(\mathrm{~s})\end{array}$ & $\begin{array}{c}0,863 \\
(\mathrm{~ns})\end{array}$ & $\begin{array}{c}0,373 \\
\text { (ns) }\end{array}$ & $\begin{array}{c}0,696 \\
\text { (ns) }\end{array}$ & $\begin{array}{r}0,147 \\
\text { (ns) }\end{array}$ & $\begin{array}{c}0,919 \\
(\mathrm{~ns})\end{array}$ & $\begin{array}{c}0,129 \\
(\mathrm{~ns}) \\
\end{array}$ \\
\hline Crops & & Mucuna & Mucuna & Cotton & Maize & Mucuna & Mucuna & Cotton & Maize \\
\hline T1. No tillage & \multirow{3}{*}{$\begin{array}{c}\text { R3 } \\
\text { 2muc-c }\end{array}$} & 965 a & 776 a & $1251^{\text {a }}$ & $2527^{a}$ & $1092^{a}$ & $521^{a}$ & $903 a$ & $2386^{a}$ \\
\hline \multirow{2}{*}{$\begin{array}{l}\text { T2. Scarifying IR } 12 \\
\text { T3. Conventional tillage }\end{array}$} & & $813^{a}$ & 632 a & $1275^{a}$ & 1590 a & $1261^{a}$ & $656^{\text {a }}$ & $1256 a$ & 2002 a \\
\hline & & 998 a & 641 a & $1191^{\text {a }}$ & $2308^{a}$ & 1377 a & $593^{a}$ & $1172 \mathrm{a}$ & $2454^{a}$ \\
\hline Probability (5\%) & & $\begin{array}{l}0,641 \\
(\mathrm{~ns})\end{array}$ & $\begin{array}{c}0,597 \\
(\mathrm{~ns})\end{array}$ & $\begin{array}{c}0,963 \\
\text { (ns) }\end{array}$ & $\begin{array}{c}0,368 \\
(\mathrm{~ns})\end{array}$ & $\begin{array}{c}0,679 \\
\text { (ns) }\end{array}$ & $\begin{array}{c}0,825 \\
\text { (ns) }\end{array}$ & $\begin{array}{c}0,430 \\
\text { (ns) }\end{array}$ & $\begin{array}{c}0,490 \\
(\mathrm{~ns})\end{array}$ \\
\hline Crops & & Mucuna & Mucuna & Mucuna & Cotton & Mucuna & Mucuna & Mucuna & Cotton \\
\hline T1. No tillage & \multirow{3}{*}{$\begin{array}{c}\text { R4 } \\
\text { 3muc-c }\end{array}$} & $755^{\text {a }}$ & 601 a & 622 a & $692^{a}$ & $1364^{\text {a }}$ & $585^{a}$ & $833^{a}$ & $944^{a}$ \\
\hline T2. Scarifying IR 12 & & 790 a & $477^{\text {a }}$ & $688^{a}$ & $771^{a}$ & $864^{a}$ & 568 a & 694 a & $873^{a}$ \\
\hline T3. Conventional tillage & & 949 a & 498 a & $693^{a}$ & $1020^{a}$ & $1087^{a}$ & 634 a & 625 a & $1097^{a}$ \\
\hline Probability (5\%) & & $\begin{array}{c}0,394 \\
\text { (ns) }\end{array}$ & $\begin{array}{c}0,625 \\
(\mathrm{~ns})\end{array}$ & $\begin{array}{c}0,598 \\
\text { (ns) }\end{array}$ & $\begin{array}{c}0,359 \\
(\mathrm{~ns})\end{array}$ & $\begin{array}{c}0,264 \\
\text { (ns) }\end{array}$ & $\begin{array}{c}0,976 \\
(\mathrm{~ns})\end{array}$ & $\begin{array}{c}0,653 \\
\text { (ns) }\end{array}$ & $\begin{array}{c}0,732 \\
\text { (ns) }\end{array}$ \\
\hline
\end{tabular}

R1 : Cotton-Maize ; R2 : Mucuna-Cotton-Maize ; R3 : Mucuna-Mucuna-Cotton-Maize ; R4 : Mucuna-Mucuna-Mucuna-Cotton. Values followed with the same letter in each column did not differ statistically according to Student-Newman-Keuls test at $5 \%$ level of probability. $s:$ significant ; ns : not significant. 


\begin{tabular}{|c|c|c|c|c|}
\hline \multirow{2}{*}{\multicolumn{5}{|c|}{$\begin{array}{l}\begin{array}{l}\text { Koulibaly et al. J. Appl. Biosci. } 2016 \quad \text { Soil tillage practices and crops rotations eff } \\
\text { chemical properties of a lixisol in Burkina Faso }\end{array} \\
\text { Table 6. Height years tillage practices and rotations effects on crops yields (2008-2015) }\end{array}$}} \\
\hline & & & & \\
\hline \multirow{2}{*}{ Treatments } & & Seed cotton & Maize & Mucuna \\
\hline & & \multicolumn{3}{|c|}{$\mathrm{Kg} \mathrm{ha}^{-1}$} \\
\hline \multirow{3}{*}{ Soil Tillage } & T1. No tillage & $862^{b}$ & 1884 a & $823^{a}$ \\
\hline & T2. Scarifying with ripper IR 12 & $1003^{a}$ & $1817^{a}$ & $792^{a}$ \\
\hline & T3. Conventional tillage & $964 \mathrm{ab}$ & $1613^{a}$ & $830^{a}$ \\
\hline \multirow{4}{*}{ Crops rotations } & R1. c-m & $797^{b}$ & $1700^{a}$ & - \\
\hline & R2. 1 muc-c-m & 983 ab & 1769 a & 911 a \\
\hline & R3. 2 muc-c-m & 849 ab & 1844 a & 824 a \\
\hline & R4.3 muc-c & $1143^{a}$ & - & $710^{b}$ \\
\hline \multirow{3}{*}{ Probability (5\%) } & Soil Tillage & 0,036 & 0,167 & 0,753 \\
\hline & Rotations & 0,031 & 0,663 & 0,006 \\
\hline & Soil Tillage $x$ Rotations & 0,048 & 0,003 & 0,438 \\
\hline
\end{tabular}

R1 : Cotton-Maize ; R2 : Mucuna-Cotton-Maize ; R3 : Mucuna-Mucuna-Cotton-Maize ; R4 : Mucuna-Mucuna-Mucuna-Cotton. Values followed with the same letter in each column did not differ statistically according to Student-Newman-Keuls test at $5 \%$ level of probability.

\section{DISCUSSION}

Tillage practices and rotations effects on soil chemical properties: Height year's experimentation results showed that soil tillage practices did not influence soil organic matter content which decrease from 2011 to 2015. Soil organic matter decline, particularly in cottonmaize and mucuna-cotton-maize rotations, was important with conventional tillage due to high level of mineralization and therefore, soil organic carbon degradation (Razafimbelo, 2005; Cookson et al., 2008; Karuma et al., 2014). Using of mucuna during two or three years in four years rotations (R3 and R4), combined to minimum tillage (IR 12 scarification), can prevent soil organic matter declining, because soil is less disturbed and better preserved (Ouattara et al., 2006; Veiga et al., 2008, Lefèvre et al., 2013). In addition, mucuna insertion into the crops rotations, improve a soil surface organic matter compared to carbon losses (Razafimbelo, 2005; Maia et al., 2010; Busari et al., 2014). During 8 years of experimentation, introduction of Mucuna into rotations did not improve nitrogen content, but it also prevented it decrease in surface as well as in depth layer of soil. Razafimbelo (2005) and Vian et al., (2009), pointed out a limited enrichment of soil by cover crop, which is significant for carbon content only on soil surface $(0-5 \mathrm{~cm})$ layer. The low level of total phosphorus and available phosphorus contents confirm the poverty in phosphorus which majorit999y characterizes soils in Burkina Faso (Lompo et al., 2009). Although statistically equivalents and compared to zero tillage, minimum and conventional tillage led to a lower total $P$ content at $0-10 \mathrm{~cm}$ layer. This depressive effect of conventional tillage on total $P$ was reduced in rotations with two or three years of leguminous plant mucuna, which protects soil from streaming and various nutrients loss, when used as cover crop (Zougmoré et al., 2006; Haruna et Nkongolo, 2015). Moreover, on this layer, available $P$ seems to be better preserved by zero tillage. Tillage increase phosphorus availability, a factor, which could involve a more important soil declining, compared to no tillage (Veiga et al., 2008; Bationo et al., 2012; Baueur et al., 2012). Compared to minimum tillage and zero tillage, conventional tillage also caused lower total $\mathrm{K}$ and available $\mathrm{K}$ contents, even in rotations R3 (2muc-c-m) and R4 (3muc-c) with mucuna insertion, during, respectively, two and three years into four years rotation. For each considered crops rotations, tillage suppression or it reduction had positive effects, particularly on $0-10 \mathrm{~cm}$ of soil, improving majority of nutrients; and confirms conventional tillage consequences on soil chemical properties (Zougmoré et al., 2006, Busari et al., 2014). The $\mathrm{pH}$ water values decreased during 2011 to 2015 in all rotations with soil tillage (conventional and minimum tillage) as well as with no tillage (direct sowing). This soil acidification, which generally results in a loss of complex exchangeable bases (Landon, 1991), accentuated with conventional tillage which caused the most important pH decrease. Differences between $\mathrm{pH}$ water values in this soil suggest liming (Fabre and Kockmann, 2002) or local calco-magnesian amendments (Koulibaly et al., 2014), to attenuate acidification. 
Tillage practices and rotations effects on crops yields: Variations of crops yields from 2008 to 2015 showed that no tillage gave same efficacy than the minimum and conventional tillage. Compared to no tillage, the conventional tillage efficacy on seed cotton yields could be explained by a better water infiltration and favourable rooting condition of cotton during years when rainfall was affected by drought (Son et al., 2004; Heddadj et al.; 2005, Vian et al., 2009). Cumulated tillage practices effects during 8 years, showed minimum tillage (scarifying with IR12) as the most efficient soil preparation technique on yields of cotton. This last technique, by its efficacy on yields confirms the interest of a minimum tillage evoked by various studies (Son et al., 2004; Razafimbelo, 2005; Busari et al., 2014) and so, could suitably replace conventional tillage. Higher maize yields

\section{CONCLUSION}

This study showed that tillage practices did not statistically influence the main soil chemical properties, in four crop rotations. Soil organic matter, nitrogen, phosphorus and potassium contents decrease with conventional tillage, whereas the $\mathrm{pH}$ slightly increased. With mucuna integration in rotations during two or three years, organic matter and nitrogen were better preserved into the soil. No tillage (direct sowing) and minimum tillage (IR12 scarification) gave the same efficacy than the conventional tillage on crop yields. Thus, the suppression of tillage or its reduction can be considered for the obtained with minimum and no tillage shows that the conventional tillage could be saved in maize production. That consolidates the recommendations of Ouattara et al., (2006) to reduce ploughing frequency in order to preserve soil fertility in cotton cropping systems. Rotations influenced significantly cotton yields because of crops successions, particularly with the introduction into these rotations of mucuna, a leguminous plant cover, which was also beneficial on maize yields. This result confirms the interest in using this leguminous plant, as cover crop since it protects soils and improves yields as well as soil chemical properties (Bado, 2002; Zougmoré et al., 2006). Without two or three years of mucuna insertion into rotation, adopting triennial mucuna-cottonmaize rotation could be recommended for its efficacy on yields.

implementation of crops without inducing depressive effect on yields. Furthermore, yields are improved in rotations integrating the leguminous cover (Mucuna) whose effects are positive in soil fertility management and production diversification. A combination of reduced tillage (scarification) with crop rotations integrating Mucuna, could contribute to a sustainable soil fertility management. Crop residues management, analysis of soil physical properties and biological modifications are suggested in future investigations of this study.

\section{ACKNOWLEDGEMENTS}

The authors thank the Cotton Inter-Professional Association of Burkina Faso (AICB) and Cotton Textile Sector Support Project (PAFICOT), for their financial contribution to this study.

\section{REFERENCES}

Bado B.V. 2002. Rôle des légumineuses sur la fertilité des sols ferrugineux tropicaux des zones guinéenne et soudanienne du Burkina Faso. Thèse de doctorat (Ph.D.), Faculté des sciences de l'agriculture et de l'alimentation. Université de Laval, Québec, 184 p.

Barro A., Zougmoré R. \& Sédogo M.P. 2009. Évaluation de la faisabilité de trois types de travail du sol: application du modèle Sarra dans le Plateau central au Burkina Faso. Sécheresse, 20(4): 338-345.

Bationo A., Waswa B., Abdou A., Bado B.V., Bonzi M., Iwuafor E., Kibunja C., Kihara J., Mucheru M., Mugendi D., Mugwe J., Mwale C., Okeyo J., Olle A., Roing K. \& Sédogo M. 2012. Overview of long term experiments in Africa. In Lessons
Learned from Long Term Soil Fertility Management Experiments in Africa, Bationo A, Waswa B, Kihara J, Adolwa I,Vanlauwe B, Saidou K (eds). Springer; 1-26.

Bauer P.J., Szogi A.A., Novak J.M. \& Vanotti M.B. 2012. Phosphorus recovered from swine wastewater as a fertilizer for cotton grown with conservation tillage. Journal of Cotton Science, 16(2): 97-104.

Busari M.A., Kukal S.S., Kaur A., Bhatt R. \& Dulazi A.A. 2015. Conservation tillage impacts on soil crop and the environment. International Soil and Water Conservation Research 3: 119-129. http://dx.doi.org/10.1016/j.iswcr.2015.05.002.

Cookson W.R., Murphy D.V. \& Roper M.M. 2008. Characterizing the relationships between soil organic matter components and microbial 
function and composition a long a tillage disturbance gradient. Soil Biology and Biochemistry, 40: 763-777.

Fabre B. \& Kockmann F. 2002. La pratique du chaulage. De la construction du référentiel régional à la démarche de conseil en exploitation. Étude et Gestion des Sols, 9(3): 213-224.

Haruna S.I. \& Nkongolo N.V. 2015. Effects of tillage, rotation and cover crop on the physical properties of a silt-loam soil. Int. Agrophys, 29: 137-145. doi: 10.1515/intag-2015-0030.

Karuma A., Mtakwa P., Amuri N., Gachene C.K. \& Gicheru P. 2014. Tillage effects on selected soil physical properties in a maize-bean Intercropping system in Mwala district, Kenya. International Scholarly Research Notices, vol. 2014, Article ID 497205,12 p. doi:10.1155 /2014/497205.

Koulibaly B., Traoré O., Dakuo D., Lalsaga R., Lompo F. \& Zombré P.N. 2014. Acidification des sols ferrugineux et ferrallitiques dans les systèmes de production cotonnière au Burkina Faso. Int. J. Biol. Chem. Sci. 8(6): 2879-2890. DOI: http://dx.doi.org/10.4314/ijbcs.v8i6.44.

Landon J.R. 1991. Booker tropical soil manual. A Handbook for soil survey and agricultural land evaluation in the tropics and subtropics. Oxon, Booker Tate Limited; Harlow, Essex: UK, Longman; $474 \mathrm{p}$.

Lefèvre V. 2013.Conception de systèmes de culture innovates pour améliorer le fonctionnement des sols en agriculture biologique. Thèse de doctorat, Agronomie, Institut des Sciences et Industries du Vivant et de l'Environnement (Agro Paris Tech), $258 \mathrm{p}$.

Lefèvre V., Capitaine M., Peigné J. \& Roger-Estrade J. 2013. Farmers and agronomists design new biological agricultural practices for organic cropping systems in France. Agronomy for Sustainable Development: 1-10. DOI: 10. 1007/s13593-013-0177-2.

Lompo F., Segda Z., Gnankambary Z. \& Ouandaogo N. 2009. Influence des phosphates naturels sur la qualité et la biodégradation d'un compost de pailles de maïs. Tropicultura, 27, 2, 105-109.

Maia S.M., Ogle S. M., Cerri C.C. \& Cerri C.E. 2010. Changes in soil organic carbon storage under different agricultural management systems in the southwest amazon region of brazil. Soil and Tillage Research, 106(2):177-184.
Mando A., Ouattara B., Somado A.E., Wopereis M.C.S., Stroosnidjer L. \& Breman H. 2005. Long-term effects of fallow tillage and manure application on soil organic matter and nitrogen fractions and on sorghum yield under sudano-sahelian conditions. Soil Use and Management, 21: 2531.

Ouattara B., Ouattara K., Serpentié G., Mando A., Sédogo M.P. \& Bationo A. 2006. Intensity cultivation induced effects on soil organic carbon dynamic in the western cotton area of Burkina Faso. Nutr Cycl Agroecosyst; 76: 331-339.

Ouédraogo J. Ouédraogo E. \& Nacro H.B. 2014. Effet de l'interaction entre des modes de gestion de fertilité et la macrofaune sur la productivité du niébé et du sorgho en zone nord soudanienne du Burkina Faso. Int. J. Biol. Chem. Sci. 8(1): 104-114. http://ajol.info/index.php/ijbcs.

Pallo F.J.P., Sawadogo N., Zombré N.P. \& Sédogo P.M. 2009. Statut de la matière organique des sols de la zone nord soudanienne au Burkina Faso. Biotechnol. Agron. Soc. Environ. 13(1): 139-142.

Pouya M.B., Bonzi M., Gnankambary Z., Koulibaly B., Ouédraogo I., Ouédraogo J.S. \& Sédogo P.M. 2013. Perception paysanne et impact agropédologique du niveau de mécanisation agricole dans les zones cotonnières Centre et Ouest du Burkina Faso. Int. J. Biol. Chem. Sci., 7(2): 489506.

Razafimbelo M.T. 2005. Stockage et protection du carbone dans un sol ferrallitique sous systèmes en semis direct avec couverture végétale des hautes terres malgaches. Thèse de doctorat en science du sol. Ecole Nationale Supérieure Agronomique de Montpellier, $145 \mathrm{p}$.

Reddy K.N., Zablotowicz R.M., Locke M.A. \& Koger C.H. 2003. Cover crop, tillage, and herbicide effects on weeds, soil properties, microbial populations, and soybean yield. Weed Science, 51: 987-994.

Schneider F., Kallis G. \& Martinez-Alier J. 2010. Crisis or opportunity? Economic degrowth for social equity and ecological sustainability. Introduction to this special issue. Journal of Cleaner Production 18, 511-518. doi:10.1016/ j.jclepro.2010.01.014.

Sawadogo H., Bock L., Lacroix D. \& Zombré N.P. 2008. Restauration des potentialités de sols dégradés à l'aide du zaï et du compost dans le Yatenga (Burkina Faso). Biotechnol. Agron. Soc. Environ. 12(3): 279-290.

Son G., Baboui M., Kambiré F. \& Bourarach E. 2004. Effets du travail du sol sur la levée et le 
développement racinaire du cotonnier sur sols ferrugineux tropicaux lessivés au Burkina Faso. Revue H.T.E., 129.

Traoré A.C. 2016. Effet du travail du sol sur les propriétés chimiques et les rendements des cultures. Mémoire de fin d'étude. Option Agronomie, CUPD, $62 \mathrm{p}$.

Veiga M., Reinert D.J., Reichert M.J., \& Kaiser D.R. 2008. Short and long-term effects of tillage systems and nutrient sources on soil physical properties of a southern Brazilian hapludox. $R$. Bras. Ci. Solo, 32:1437-1446.

Vian J.F. 2009. Comparaison de différentes techniques de travail du sol en agriculture biologique: Effet de la structure et de la localisation des résidus sur les microorganismes du sol et leurs activités de minéralisation du carbone et de l'azote. Thèse de doctorat. Agronomie, Institut des Sciences et Industries du Vivant et de I'Environnement (Agro Paris Tech), $172 \mathrm{p}$.

Vian J.F., Peigné J., Chaussod R. \& Roger-Estrade J. 2009. Effets du mode de travail du sol sur les microorganismes à l'échelle du profil cultural. Étude et Gestion des Sols, 16, 3/4: 355 -364.

Yaméogo J.T., Somé A.N., Mette Lykke A., Hien M. \& Nacro H.B. 2013. Restauration des potentialités de sols dégradés à l'aide du zaï et des cordons pierreux à l'Ouest du Burkina Faso. Tropicultura, 31(4): 224-230.

Zougmoré R., Nagumo F. \& Hosikawa A. 2006. Nutrient uptakes and maize productivity as affected by tillage system and cover crops under the subtropical climate at Ishigaki, Okinawa, Japan. Soil Science \& Plant Nutrition, 52: 509-518. 